\title{
PENDIDIKAN MULTIKULTURAL DI SMAN 1 MASALEMBU SUMENEP \\ (Studi Pada Mata Pelajaran Pendidikan Agama Islam Aspek Fiqh)
}

\author{
Miftahol Arifin \\ (STAI Al-Khairat Pamekasan) \\ Miftah.abibilqist@gmail.com
}

\begin{abstract}
The variety of culture in small islands of Sumenep regency has some uniqueness to be observed. For instance, the ethnic group in Masalembu island consist of Bugis, Mandar, Button, Bajo, Java and Madurese. That culture variety (multiculture) need an education innovation especially in Islamic education at Masalembu Junior High School 1 Sumenep. Multiculture education is a learning way that is oriented to the process of making personality and attitude of students to make them understand about plurality, equality, and tolerance to others in the society. Furthermore, the writer try to observe about Multiculture Education at Masalembu Junior High School 1 Sumenep through a teaching model to Islamic education subject of Fiqh side which the students condition is vary in ethnic groups and culture. This research is a qualitative field research using descriptive approach. The data collection in this research using observation, interview, and documentation. The result of the research shows that Multiculture Education through acomodative strategy is a learning process that give knowledge to the students about culture, tradition, attitude patterns in society and become an identity for future progress of individually and the society itself. Through this teaching strategy Multiculture Education can be applied in Masalembu Junior High School 1 Sumenep. Acomodative Learning Model at Masalembu Junior High School 1 Sumenep has a clear lesson plan, so that students able to have appreciatiation and positive impact to the students who has different culture in the classroom and able to understand the culture variety in their society. The students' appreciation in the classroom shows that they have pluralist attitude. There is no differences or similarity and tolerance to their friends inside or outside the classroom. Whereas, the appreciation of students to the society shows that the students able to understand the differences between Islamic education of Fiqh side that they received at school and the plurality of culture in their society.

Keywords: Multiculture Education, Acomodative.
\end{abstract}


Miftahol Arifin, Pendidikan Multikultural di SMAN 1 Masalembu Sumenep (Studi Pada Mata Pelajaran Pendidikan Agama Islam Aspek Fiqh)

\begin{abstract}
Abstrak
Keragaman budaya Kepulauan Sumenep memiliki keunikan yang perlu diteliti. Suku-suku di Kepulauan Masalembu Sumenep misalnya, terdiri dari suku Bugis, Mandar, Button, Bajo, Jawa dan Madura.Keanekaragaman budaya (multikultur) tersebut memerlukan inovasi pendidikan dan pembelajara khususnya mata pelajaran Pendidikan Agama Islam di SMAN 1 Masalembu Sumenep.Pendidikan Multikultural merupakan pembelajaran yang berorientasi pada proses pembentukan personalitas dan sikap siswa agar memahami pluralitas, equality dan toleransi terhadap sesama dan masyarakatnya. Olehnya, penulis akan mencoba meneliti tentang Pendidikan Multikultural di SMAN 1 Masalembu Sumenep melalui model pembelajaran yang dilakukan pada mata pelajaran PAI aspek Fiqh yang kondisi siswanya beragam suku dan budaya. Penelitian ini merupakan penelitian lapangan (field research) yang bersifat kualitatif dengan menggunakan pendekatan deskriptif. Pengumpulan data dalam penelitian ini menggunakan teknik pengamatan, wawancara, dan dokumentasi. Hasil penelitian menunjukkan bahwa Pendidikan Multikultural melalui model Strategi Pembelajaran Akomodatif merupakan proses pembelajaran yang memberikan keluasan kepada siswa untuk memahami budaya, tradisi, pola-pola kelakuan yang hidup dalam masyarakat yang melekat dan menjadi identitas dalam masyarakat untuk kemajuan diri dan masyarakatnya. Melalui model Pembelajaran Akomodatif ini pendidikan multikultural dapat dilaksanakan di SMAN 1 Masalembu Sumenep. Model Pembelajaran Akomodatif di SMAN 1 Masalembu Sumenep mempunyai RPP yang jelas sehingga siswa mampu mempunyai apresiasi dan dampak yang positif terhadap siswayang memilki budaya yang berbedadi kelasdan mampu memahami keragaman budaya masyarakatnya. Apresiasi siswa di kelas menunjukkan bahwa siswa mempunyai sikap pluralis, tidak ada perbedaan/kesamaan dan toleransi terhadap temannya di kelas maupun di luar kelas. Sedangkan apresiasi siswa terhadap masyarakatnya menunjukkan bahwa siswa mampu memahami perbedaan antara teks mata pelajaran PAI aspek Fiqh yang diterima di sekolah dengan pluralitas budaya yang terjadi di masyarakat sekitarnya.
\end{abstract}

Kata Kunci: Pendidikan Multikultural, Akomodatif.

\title{
Pendahuluan
}

Pendidikan mempunyai peranan penting dalam seluruh aspek kehidupan manusia, karena pendidikan berpengaruh langsung terhadap perkembangan seluruh aspek kepribadian manusia. Pendidikan merupakan sebuah proses yang bertujuan untuk membentuk manusia menjadi menjadi manusia seutuhnya, artinya melalui pendidikan diharapkan manusia mampu mengembangkan potensinya secara optimal melalui ke- 
mampuan berbahasa, berpikir dan bertindak. Oleh karena itu, penekanan dalam proses pendidikan terletak pada pembentukan kesadaran diri dan kepribadian siswa di samping sebagai upaya mentransfer ilmu pegetahuan dan keterampilan.

Pendidikan adalah bimbingan secara sadar dalam rangka mengembangkan jasmani dan ruhani siswa menuju terbentuknya manusia yang berkepribadian. Setiap proses pendidikan akan berusaha mengembangkan seluas-luasnya potensi individu sebagai anugerah dari Allah SWT serta menjadi sebuah elemen penting untuk mengembangkan dan mengubah masyarakat ${ }^{1}$.

Ironisnya perkembangan penyelenggaraan pendidikan saat ini banyak disorot karena ada anggapan bahwa muatan kurikulum pendidikan yang diterapkan belum mampu memproporsikan potensi siswa. Proses pendidikan terkadang diidentikkan dengan orientasi kurikulum yang terlampau menitikberatkan pada aspek konitif manusia sehingga aspek psikomotorik dan sikap relatif terabaikan dan hal ini akan menyebabkan ketidakseimbangan terhadap perkembangan siswa.

Pendidikan agama Islam di sekolah yang seyogyanya lebih banyak berorientasi pada mengembangan dan pembiasaan sikap, moral, etika dan akhlakul karimih; kini masih menjadi masalah laten, nilai rapot tetap lebih banyak dijadikan indikator utama dalam menentukan prestasi siswa. Seakan kemampuan sikap terabaikan walau sebenanya pada sikap ini menjadi tumpuan yang sebenarya keberhasilan pendidikan agama Islam diukur. Kemampuan bersosialisasi, dan toleransi menjadi modal utama dalam menjalin hubungan berbangsa dibumi NKRI.

Hidup di Negara Kesatuan Republik Indonesia (NKRI) yang memiliki banyak keanekaragaman budaya dan bahasa memerlukan kemampuan toleransi lebih demi terciptanya keharmonisan. Kemampuan ini perlu dibiasakan sejak usia dini dan remaja yang perlu dilakukan di sekolah-sekolah dan lingkungan keluarga. Mata pelajaran yang mengakomudir kemampuan toleransi ini adalah pendidikan agama Islam. Sedangkan pendekatan yang biasa dipakai adalah pendidikan multikultural dengan strategi pembelajaran akomudatif.

Paradigma Pendidikan Multikultural diterapkan di sekolah sebagai sebuah pendekatan pendidikan yang mempunyai wawasan yang toleran dan terbuka dalam proses

\footnotetext{
${ }^{1}$ Ahmad D. Marimba, Pengantar Filsafat Pendidikan Islam, (Bandung: PT al-Ma'arif, 1998), 19.
} 
Miftahol Arifin, Pendidikan Multikultural di SMAN 1 Masalembu Sumenep (Studi Pada Mata Pelajaran Pendidikan Agama Islam Aspek Fiqh)

pengajaran dan pembelajaran kepada siswa yang mempunyai latar belakang budaya, suku dan etnis yang berbeda sebagaimana telah diterapkan di SMAN 1 Masalembu Sumenep.

SMAN 1 Masalembu Sumenep adalah satu-satunya sekolah menengah negeri yang terdapat di Kepulauan Masalembu Sumenep. Masalembu merupakan salah satu wilayah kecamatan di Kabupaten Sumenep yang bertipologi kepulauan. Kepulauan Masalembu memiliki pluralitas suku dan etnis yaitu; Suku Jawa, Madura, Bugis, Mandar, Button dan Bajo. Keberagaman suku/etnis Kepulauan Masalembu mempengaruhi tradisi sosial dan keberagamaan sehari-hari seperti tentang shalat Jenazah, shalat Khusuf, Peroses perkawinan, jual beli dan lain-lain. Suku Bugis, Mandar, Button dan Bajo menganggap bahwa melakukan Shalat Jenazah adalah pamali atau dilarang secara adat, sedangkan suku Jawa dan Madura Shalat Jenazah adalah tidak pamali. Tradisi suku Bugis dalam shalat khusuf atau shalat gerhana rembulan adalah anak-anak perempuan mereka dibangunkan kemudian dimandikan air tujuh sumur. Proses perkawinan tradisi dan adat suku Bugis, Mandar, Button dan Bajo mempunyai kebiasaan "tawarmenawar" antara pihak perempuan dan laki-laki dalam khitbah dan maskawin/mahar dengan harga yang sangat tinggi yaitu mencapai Rp. 25 juta. Tradisi jual beli masyarakat lebih cenderung jual beli "urub" yaitu jual beli barter atau barang dengan barang.

Keragaman budaya tersebut mempengaruhi terhadap proses belajar mengajar khususnya mata pelajaran PAI aspek Fiqh di SMAN 1 Masalembu Sumenep dimana kurikulum mata pelajaran PAI memberikan acuan pembelajaran standar ke-Fiqh-an bahwa Shalat Jenazah hukumnya fardlu kifayah, shalat khusuf hukumnya sunnah, pernikahan menitik beratkan pada syarat dan rukun sedangkan jual beli "urub" atau barter adalah dilarang dalam Islam.

Kontradiksi tersebut sangat menarik untuk diteliti bagaimana pendidikan mampu menampung kontradiksi antara teks/mata pelajaran dengan realitas budaya masyarakat yang beragam. Sebuah kasus multikultural di SMAN 1 Masalembu Sumenep akan memberikan sebuah telaah; pertama, tentang model metode pembelajaran yang diberikan kepada siswa akan berlainan dengan model metode pembelajaran di sekolah yang tidak memiliki latar belakang Multikultural. Kedua adalah apresiasi tingkah laku siswa yang meliputi persepsi dan tindakan siswa terhadap budaya lain. 
Berangkat dari latar belakang pemikiran tersebut, maka penulis terdorong untuk melakukan penelitian tentang: Pendidikan Multikultural di SMAN 1 Msalembu Sumenep (Studi pada Pembelajaran PAI aspek Fiqh). Problem akademik yangdijawab dalam penelitian ini adalah Bagaimanakah model pembelajaran Fiqh di SMAN 1 Masalembu Sumenep berhadap-hadapan dengan latar budaya/tradisi keberagamaan siswa yang berbeda? Serta bagaimana apresiasi siswa terhadap keragaman budaya lain dalam proses belajar mengajar di SMAN 1 Masalembu Sumenep?

\section{Kerangka Teoritik}

Ada tiga diskursus dalam mengidentifikasi Pendidikan Multikultural yaitu; pertama, masalah kebudayaan, kedua, kebiasaan-kebiasaan, tradisi, pola-pola kelakuan yang hidup dalam masyarakat dan ketiga, kemajuan tertentu dari kelompok-kelompok dalam masyarakat yang merupakan identitas dan melekat dalam masyarakat. ${ }^{2}$

Ketiga diskursus di atas, memberikan spirit untuk merancang model pembelajaran yang disesuaikan dengan kondisi sosial-budaya yang ada seperti halnya model pembelajaran Fiqh yang berbeda antara materi Fiqh-pelaksanaan tradisi Fiqh-siswa yang beragam suku/budaya. Perbedaan ini akan menghasilkan konflik siswa dalam skala kecil dan masyarakat dalam implementasinya sehari-hari. Olehnya, memerlukan model pembelajaran yang akomodatif sebagai konsekwensi dari keragaman suku/budaya yang dimiliki siswa.

Model pembelajaran akomodatif merupakan proses pembelajaran yang memberikan keluasan kepada siswa untuk memahami budaya, tradisi, pola pola kelakuan yang hidup dalam masyarakat yang melekat dan menjadi identitas dalam masyarakat untuk kemajuan diri dan masyarakatnya. Melalui model pembelajaran akomodatif inilah pendidikan multikultural dapat dilaksanakan/tercapai sebagaimana diterapkan terhadap proses pembelajaran Fiqh di SMAN 1 Masalembu Sumenep.

Apresiasi terhadap perilaku siswa dalam memahami budaya lain yang telah diajarkan menjadibahan evaluasi yang sangat penting dimana kerangka budaya masyarakat yang beragam-model pembelajaran yang akomodatif-tingkah laku siswa terhadap budaya lain merupakanwujud satu kesatuan proses pembelajaran yang bertumpu pada paradigma pendidikan Multikultural. Pendidikan Multikultural mempunyai tujuan per-

\footnotetext{
${ }^{2}$ H.A.R. Tilaar, Perubahan Sosial dan Pendidikan: Pengantar Pedagogik Transformatif untuk Indonesia, (Jakarta: Grasindo.2002), 168
} 
Miftahol Arifin, Pendidikan Multikultural di SMAN 1 Masalembu Sumenep (Studi Pada Mata Pelajaran Pendidikan Agama Islam Aspek Fiqh)

tama, membentuk "manusia budaya" dan menciptakan "masyarakat manusia berbudaya”. Kedua, materi pendidikan Multikultural adalah mengajarkan nilai-nilai luhur kemanusiaan, nilai-nilai bangsa dan nilai-nilai kelompok etnis. Ketiga, metode yang diterapkan adalah metode yang demokratis dan akomodatif yang menghargai aspekaspek perbedaan dan keberagaman budaya bangsa dan kolompok etnis. Keempat, evalusi yang diterapkan adalah bersifat mengevaluasi tingkah laku siswa yang meliputi persepsi, apresiasi dan tindakan siswa terhadap budaya lain.

Kajian tentang Pendidikan Multikultural di Indonesia sekarang ini marak sekali dilakukan oleh ahli pendidikan seperti H.A.R. Tilaar (2004) dalam karyanya Multikulturalisme; Tantangan-tantangan Global Masa Depan dalam Transformasi Pendidikan Nasional, M. Ainul Yaqin (2005) dalam karyanya Pendidikan Multikultural; CrossCultural Understanding Untuk Demokrasidan Keadilan, Maslikah (2007) dalam karyanya Quo Vadis Pendidikan Multikultur; Rekonstruksi Sistem Pendidikan berbasis kebangsaan, Zakiyuddin Baidhawy (2005) dalam bukunya Pendidikan Agama Berwawasan Multikultural dan lain sebagainya.

H.A.R. Tilaar membedah Pendidikan Multikultural pada sisi realitas masa depan dan tantangan yang dihadapi. Pendekatan yang digunakan adalah histories-kritis. Pendidikan Multikultural merupakan kebutuhan logis dari masyarakat yang mempunyai ragam budaya dan agama. Di pentas dunia termasuk Indonesia yang memang sudah memiliki keragaman budaya paradigmaPendidikan Multikultural menjadi sangat urgen. H.A.R Tilaar mencoba memaparkan kerangkan Pendidikan Multikultural dari sudut sejarah, ideology dan upaya penerapannya di Negara-negara yang mempunyai akar budaya Multikultural termasuk di Indonesia. Menurutnya, pendidikan Multikultural berawal dari berkembangnya gagasan dan kesadaran tentang "interkulturalisme" seusai perang dunia ke II. Kemunculan gagasan dan kesadaran ini terkait dengan perkembangan politik internasional menyangkut HAM, kemerdekaan dari kolonialisme, diskriminasi rasial dan lain-lain, juga karena meningkatnya pluralitas Negara barat sendiri sebagai akibat dari peningkatan migrasi dari Negara-negara yang baru merdeka ke Amerika dan Eropa. Program pendidikan Multikultural fokus tidak lagi diarahkan semata-mata kelompok sosial, kultural dominan atau mainstream, dan agama melainkan dia- 
rahkan pada sikap "peduli" atau mau mengerti dan politik pengakuan terhadap orangorang dari kelompok minoritas. ${ }^{3}$

M. Ainul Yaqin lebih menekankan pentingnya Pendidikan Multikultural dari pendekatan konflik dan kondisi "carut marut" dalam persoalan perseteruan politik, korupsi, kolusi, nepotisme, premanisme, kemiskinan, kekerasan, saparatisme perusakan lingkungan dan hilangnya rasa kemanusiaan untuk selalu menghormati hak-hak orang lainyang melanda bangsa Indonesia. Asumsi dasar Yaqin dalam tulisannya menyebutkan bahwa mengapa bangsa Indonesia yang terbingkai dalam Negara Kesatuan Republik Indonesia (NKRI) menjadi tercabik-cabik karena adanya multibudaya, gender, partai dan agamayang saling bersitegang satu sama lain. Dari sana Yaqin menawarkan Pendidikan Multikultural menjadi solusi dalam mengurai problematika bangsa ${ }^{4}$.

Muslikhah memberikan kerangka pentingnya Pendidikan Multikultural pada sisi teori termasuk kemungkinan-kemungkinan Pendidikan Multukultural diterapkan pada Pendikan Islam. Pendidikan Islam yang berbasiskan pada multikulturalisme dilakukan sebagai transformasi transidental yaitu pendidikan yang mampu memperkokoh rasa cinta tanah air, setia kawan, dan bertanggung jawab atas kesejehteraan masyarakat untuk semua kultur sosial yang dijiwai pada nilai-nilai keIslaman. ${ }^{5}$

Pentingnya pendidikan Islam berwawasan Multikultural ini juga dielaborasi oleh Zakiyuddin Baidhawi dalam bukunya Pendidikan Agama Berwawasan Multikultural. Pendidikan Agama didesain untuk menawarkan nilai-nilai saling pengertian, interdepedensi, dan perdamaian. Baidhawi mengharapkan agar meninggalkan pola pendidikan Agama yang selama ini ada yaitu pendidikan Agama yang kaku menuju pendidikan Agama yang menggunakan pendekatan transidental. Harapan selanjutnya adalah dimungkinkannya pendekatan kontekstual dan dialogissebagai konsekwensi memahami lebih jauh pluralitas individu untuk memahamkan dan mengakui adanya identitasidentitas yang plural. Pencerahan antara Teologi dan karya ilmiyah menurut Baidhawi juga memberikan andil yang besar dalam mendukung adanya pendidikan Agama yang berwawasan Multikultural. $^{6}$

\footnotetext{
${ }^{3}$ H.A.R. Tilaar, Perubahan Sosial.., 495-498.

${ }^{4}$ M. Ainul Yaqin, Pendidikan..., 3-5.

${ }^{5}$ Muslikhah, Quo Vadis..., 162.

${ }^{6}$ Zakiyuddin Baidhawi, Pendidikan Agama Berwawasan Multikultural, (Jakarta: Erlangga, 2005), 124-7.
} 
Miftahol Arifin, Pendidikan Multikultural di SMAN 1 Masalembu Sumenep (Studi Pada Mata Pelajaran Pendidikan Agama Islam Aspek Fiqh)

Ainurrofiq Dawam menawarkan Pendidikan Multikultural atas dasar krisis “sekolah" yang justru mengeksploitasi sebagai ajang bisnis. "Sekolah" bukan lagi milik semua tetapi milik mereka yang hanya mempunyai uang. Menurut Rofiq ada dua hal yang menjadikanpendidikan Multikultural begitu penting yaitu; pertama, faktor internal yaitu pengalaman penulis selama menjalani pendidikan tidak pernah diajarkan dan diperkenalkan secara intens tentang penghormatan terhadap heterogenitas dan pluralitas masyarakat Indonesia, dan juga adanya kegamangan dan ambigutasantara realitas yang ada dalam wacana pendidikan dan realitas yang ada dalam praktek pendidikan. Kedua, faktor eksternal yaitu realitas bahwa Negara Indonesia adalah Negara yang dihuni oleh berbagai suku, bangsa, etnis, dengan bahasa, budaya, tradisi dan peradaban yang beragam. $^{7}$

Rofiq menekankan pentingnya Pendidikan Multikulturalisme diterapkan di Indonesia karena beberapa alasan yaitu; pertama, Pendidikan Multikultural secara inheren sudah melekat dan ada sejak bangsa Indonesia ini ada. Kedua, Pendidikan Multikultural memberikan secercah harapan dalam mengatasi berbagai gejolak masyarakat yang sekarang ini sering terjadi. Ketiga, Pendidikan Multikultural menentang pendidikan yang berorientasi bisnis. Ke-empat, Pendidikan Multikultural sebagai resistensi fanatisme yang mengarah pada berbagai jenis kekerasan.

Maksum dan Ruhendi menelaah paradigma pendidikan dengan berbagai model pemikiran termasuk Pendidikan Multikultural. Penekanan reparadigmatik konsep pendidikan perlu selalu ditumbuhkan agar sesuai dengan realitas sosial budaya masyarakat. Pada konteks inilah pendidikan Multukultural menjadi bagian dari paradigmatik pendidikan masa depan karena kondisi masyarakat sekarang yang plural sehingga membantu siswa mengerti, menerima dan menghargai orang dari suku, budaya, nilai dan agama yang berbeda. ${ }^{8}$

Analitik perlunya Pendidikan Multikultural di Indonesia juga dilontarkan oleh Agus Salim dalam buku yang di editnya "Indonesia Belajarlah: Membangun Pendidikan Indonesia”. Tulisan Agus Salim dalam sesi Pendidikan Multikultural menganggap bahwa pendidikan nasional yang sekarang dikembangkan menunjukkan fenomena yang tidak menguntungkan bagi pembentukan proses kultural. Hal ini disebabkan karena

\footnotetext{
${ }^{7}$ Ainurrofiq Dawam, Emoh...,19-25.

${ }^{8}$ Ali Maksum dan Luluk Yunan Ruhendi Maksum, Paradigma pendidikan Universal di Era Modern dan Post-Modernisme, (Jogyakarta: IRCiSod., 2004),189-191 dan 240.
} 
pendidikan nasional bersifat molitik-kultural, etnosentrisme dengan menempatkan budaya induk sebagai acuan atau standard superioritas, sehingga sangat merugikan bagi pembentukan integrasi nasional. Kedua, sistem pendidikan barat yang terlalu diakomodasi kedalam pendidikan nasional. Ketiga, keindonesiaan tidak cukup dibangun dengan identitas sub-nasional dengan basis ras, etnik, budaya, kelas sosial, agama dan pengelompokan lainnya. Ke-empat, dunia pendidikan nasional cenderung elitis untuk mempertahankan status quo dalam struktur sosial yang mapan, oleh sebab itu pendidikan Indonesia terjebak pada homogenitas penyeragaman dengan standar "Kultur Nasional". 9

Telaah teori dan praktek Pendidikan Multikultural dielaborasi secara runtut oleh Christin I. Bennett dalam tulisannya yang berjudul Comprehensive Multicultural Education: Theory and Practice. Bennett memaparkan pendekatan multikultural dilatarbelakangi oleh keragaman etnik dan komunitas di Amerika yang dengan sendirinya akan berhadap-hadapan dengan koneksi global. Konteks inilah Bennett tidak hanya memaparkan secara teoritik konsep Pendidikan Multikultural akan tetapi lebih jauh pada proses pengajaran, pembelajaran dan kurikulum. ${ }^{10}$

Pendapat ini akan menjadi salah satu acuan penulis dalam mengelaborasi pendidikan Multikultural secara teoritik dan praktis disamping buku-buku lain seperti Buku Manning dan Barruthyang berjudul Multicultural Education of Children and Adolescents. Tidak jauh dengan buku Bennett, Manning menekankan pada aplikasi pendidikan Multikultural di sekolah, definisi, aplikasi dan masa depan pendidikan Multikultural memungkinkan untuk dilaksanakan sejak anak-anak sampai usia remaja sebagai bekal dalam memahami keragaman budaya. Manning memberikan contoh pada pendidikan di Amerika yang sangat mungkin terdapat siswa yang mempunyai latar belakang budaya yang berbeda. ${ }^{11}$

Gwendolyn C. Baker menawarkan prinsip-prinsip pendidikan Multikultural yang merupakan basis pengembangan pendidikan. Pertama, pendidikan Multikultural merupakan sebuah proses. Kedua, pengembangan terhadap pendekatan Multikultural

\footnotetext{
9 Agus Salim, "Pendidikan Multikultural" dalam Indonesia Belajarlah: Membangun Pendidikan Indonesia, (Semarang: Gerbang Madani Indonesia., 2004), 315.

${ }^{10}$ Christin I. Bennett, Comprehensive Multicultural Education: Theory and Practice, (Amerika: A Simon \& Schuster Company. 1995), 13.

${ }^{11}$ Manning dan Barruth, Multicultural Education of Children and Adolescent, (Amerika: A Pearson Education Company). 20003.
} 
Miftahol Arifin, Pendidikan Multikultural di SMAN 1 Masalembu Sumenep (Studi Pada Mata Pelajaran Pendidikan Agama Islam Aspek Fiqh)

pada pendidikan harus comprehensive dan lengkap. Ketiga, pendidikan Multikultural harus dibangun dalam lingkungan yang kondusif dan supportive. Ke-empat, semua komponen dalam sekolah harus mendukung pada pengembangan pendidikan Multikultural. Kelima, sangat penting dilakukan pelatihan dan pendidikan terhadap staf, guru, orang tua dan tokoh-tokoh masyarakat tentang pendidikan Multikultural. Ke-enam, Pendidikan Multikultural akan bergerak dari latar belakang siswa sebagai proses yang penting. Ketujuh, pengembangan pendidikan Multikultural berkelanjutan terus menerus. Kedelapan komponen intruksionalpendidikan Multikultural harus terintegrasikan dalam kurikulum sekolah. Prinsip-prinsip tersebut memberkan peluang terwujudnya pendidikan Multikultural yang sistematis dan berkelanjutan. ${ }^{12}$

\section{Pendidikan Multikultural}

Pendidikan merupakan sistem dan cara meningkatkan kualitas hidup manusia dalam segala aspek kehidupan manusia. Dalam sejarah umat manusia, hampir tidak ada kelompok manusia yang tidak menggunakan pendidikan sebagai alat pembudayaan dan peningkatan kualitasnya, sekalipun dalam masyarakat yang masih terbelakang (primitive). Pendidikan sebagai usaha sadar yang dibutuhkan untuk menyiapkan anak manusia demi menunjang perannya di masa datang.

Istilah "multi budaya" (multi culture) jika ditelaah asal-usulnya mulai dikenal sejak tahun 1960-an, setelah adanya gerakan hak-hak sipil sebagai koreksi terhadap kebijakan asimilasi kelompok minoritas terhadap melting pot yang sudah berjalan lama tentang kultur dominan Amerika khususnya di New York dan California. ${ }^{13}$ Will Kymlicka berpendapat, multibudaya merupakan suatu pengakuan, penghargaan dan keadilan terhadap etnik minoritas baik yang menyangkut hak-hak universal yang melekat pada hak-hak individu maupun komunitasnya yang bersifat kolektif dalam mengekspresikan kebudayaannya. ${ }^{14}$

Berbeda dengan Stavenhagen yang memandang bahwa konsep "multibudaya" mengandung dua pengertian; pertama, multibudaya merupakan realitas sosial dalam masyarakat yang heterogen. Pernyataan dari segi ini sebanyak 95\% Negara-negara di dunia pada dasarnya adalah bersifat multibudaya mengingat secara etnis dan budaya

\footnotetext{
${ }^{12}$ Gwendolyn C. Baker, Planning and Organizing for Multicultural Instruction, Amerika: AddisonWesley Publishing Company. 1994, 9-10.

${ }^{13}$ Banks, Teaching Strategies For Ethnic Studies, Newton: Allyn and Bacon 1984, 3 dan 164.
} 
bersifat plural. Kedua, multibudaya telah diangkat sebagai suatu keyakinan, ideologi, sikap, maupun kebijakan yang menghargai pluralisme etnik dan budayanya sebagai sesuatu yang berharga, potensial, yang harus dipelihara dan ditumbuhkembangkan. ${ }^{15}$

Judistira K. Garna berpendapat bahwa dalam masyarakat majemuk (plural society), terdapat dua tradisi dalam sejarah pemikiran sosial. Pertama, bahwa kemajemukan itu merupakan suatu keadaan yang memperlihatkan wujud pembagian kekuasaan di antara kelompok-kelompok masyarakat yang bergabung atau bersatu, dan rasa menyatu itu dibangun melalui dasar kesetiaan (cross-cutting) kepemilikan nilai-nilai bersama dan perimbangan kekuasaan. Kedua, dalam masyarakat majemuk dikaitkan dengan relasi antar ras/etnik, bahwa masyarakat majemuk adalah masyarakat yang terdiri dari berbagai kelompok ras/etnik yang berada dalam satu sistem pemerintahan, oleh karena itu sering mengalami konflik dan paksaan. ${ }^{16}$

Implikasi dari adanya masyarakat majemuk tersebut diatas, maka masyarakat akan memiliki berbagai kelompok budaya yang beragam. Masyarakat yang memiliki budaya beragam ini maka terminologi multibudaya sering didiskusikan baik sebagai respon menghadapi tantangan realitas sosial, pengakuan atas diversitas budaya majemuk maupun pembahasan tentang pendidikan multikultural.

Istilah multibudaya (multicultural) tersebut selalu melekat dengan pendidikan, yang mempunyai arti secara luas meliputi any set of processes by which schools work with rather than against oppressed groups. ${ }^{17}$

Pendidikan multikultural berasal dari dua kata pendidikan dan multikultural. Pendidikan merupakan proses pengembangan sikap dan tata laku seseorang atau sekelompok orang dalam usaha mendewasakan manusia melalui pengajaran, pelatihan, proses, perbuatan dan cara-cara yang mendidik. Disisi lain Pendidikan adalah Transfer of knowledge atau memindah ilmu pengetahuan. Sedangkan Multikultural secara etimologis multi berarti banyak, beragam dan aneka sedangkan kultural berasal dari kata culture yang mempunyai makna budaya, tradisi, kesopanan atau pemeliharaan. ${ }^{18}$

\footnotetext{
${ }^{14}$ Kymlicka, Kewargaan Multikultural, alih bahasa Edlina Hafmini Eddin, (Jakarta: LP3ES, 2008), 24.

${ }^{15}$ Stavenhagen, Problems and Prospects of Multiethnic States, (Tokyo: United Nations University Press, 1986), 23.

16 Judistira K. Garna, Ilmu-ilmu Sosial: Dasar-Konsep-Posisi, (Bandung: Primaco Akademika, 2003), 164-165

${ }^{17}$ Sleeter, "Restrusturing Schools for Multicultural Education", dalam Journal of Teacher Education ed. 43., 1992141- 148.

${ }^{18}$ Ainurrofiq Dawam, Emoh...,100-101.
} 
Miftahol Arifin, Pendidikan Multikultural di SMAN 1 Masalembu Sumenep (Studi Pada Mata Pelajaran Pendidikan Agama Islam Aspek Fiqh)

Rangkaian kata pendidikan dan multikultural memberikan arti secara terminologis adalah proses pengembangan seluruh potensi manusia yang menghargai pluralitas dan heterogenitasnya sebagai konsekwensi keragaman budaya, etnis, suku dan aliran (agama). Zakiyuddin Baidhawi mendefinisikan pendidikan multikultural adalah suatu cara untuk mengajarkan keragaman (teaching diversity). ${ }^{19} \mathrm{M}$. Ainul Yaqin memahami pendidikan multikultural sebagai strategi pendidikan yang diaplikasikan pada semua jenis mata pelajaran dengan cara menggunakan perbedaan-perbedaan kultural yang ada pada para siswa seperti perbedaan etnis, agama, bahasa, gender, klas sosial, ras, kemampuan dan umur agar proses belajar menjadi mudah. ${ }^{20}$ John W. Santrock mendefinisikan pendidikan multikultural adalah pendidikan yang menghargai diversitas dan mewadahi prespektif dari beragam kelompok kultural atas dasar basis regular. ${ }^{21}$

Suparta mencatat lebih dari sepuluh definisi tentang pendidikan multikultural, diantaranya adalah pendidikan multicultural adalah sebuah pendekatan pengajaran dan pembelajaran yang didasarkan atas nilai-nilai demokratis yang mendorong berkembangnya pluralisme budaya; dalam hampir seluruh bentuk komprehensifnya. Pendidikan multikultural merupakan sebuah komitmen untuk meraih persamaan pendidikan, mengembangkan kurikulum yang menumbuhkan pemahaman tentang kelompokkelompok etnik dan memberangus praktik-praktek penindasan. ${ }^{22}$

Blum menjelaskan bahwa pendidikan multikultural meliputi sebuah pemahaman, penghargaan dan penilaian atas budaya seseorang, dan sebuah penghormatan dan keingintahuan tentang budaya etnis orang lain. Ia meliputi penilaian terhadap kebudayaan-kebudayaan orang lain, bukan dalam arti menyetujui seluruh aspek dari kebudayaan-kebudayaan tersebut, melainkan mencoba melihat bagaimana kebudayaan tertentu dapat mengekspresikan nilai bagi anggota-anggotanya sendiri.

Blum membagi tiga elemen dalam pendidikan multikultural; pertama, menegaskan identitas kultural seseorang, mempelajari dan menilai warisan budaya seseorang. Kedua, menghormati dan memahami tentang etnik/kebudayaan-kebudayaan selain kebudayaannya. Ketiga, menilai dan merasa senang dengan perbedaan kebudayaan itu sendiri; yaitu memandang keberadaan dari kelompok-kelompok budaya yang berbeda

\footnotetext{
${ }^{19}$ Zakiyuddin Baidhawi, Pendidikan....8

${ }^{20}$ M. Ainul Yaqin, Pendidikan..., 25.

${ }^{21}$ John W. Santrock, Psiqologi Pendidikan, alih bahasa Tri Wibowo B.S. (Jakarta: Kencana, 2007), 184.
} 
dalam masyarakat seseorang sebagai kebaikan yang positif untuk dihargai dan dipeliha$\mathrm{ra}^{23}$

Berdasarkan Suparta dan Blum di atas dapat disimpulkan bahwa pendidikan multikultural merupakan proses pengembangan sikap, sopan dan santun dalam rangka menerima dan menghargai budaya orang lain.

\section{Masalembu dan Multikulturalisme}

Kepulauan Masalembu merupakan salah satu wilayah kecamatan di Kabupaten Sumenep yang bertipologikepulauan yang memiliki 3 pulau. Pulau-pulau di Kepulauan Masalembu mempunyai potensi keindahan alam yang sangat natural dari sisi kelautan seperti terumbu karang yang indah, species ikan yang sangat banyak dan memiliki pesona hutan mangrove yang genuine. Kepulauan Masalembu Sumenep dihuni sekitar 18.753 jiwa dengan mata pencaharian mayoritas nelayan. Sosio-kultural masyarakat Kepulauan Masalembu adalah multi-etnik yaitu beragam suku masyarakat Kepulauan Masalembu seperti suku Jawa, Madura, Mandar, Bugis, Bajo dan Button. Keragaman suku inilah yang menjadikan Kepulauan Masalembu mempunyai potensi budaya yang sangat beragam yaitu budaya yang berbeda antara satu dengan yang lain.

Keterangan di atas, menempatkan Kepulauan Masalembu memiliki dua realitas multikultural yaitu; pertama multikultural internal adalah ada dengan sendirinya bahwa multikulturalitas Kepulauan Masalembudidasarkan atas keragaman sosio-kultural Kepulauan Masalembuseperti suku dan budaya Jawa, Madura, Mandar, Bugis, Button dan Bajo. Kedua, multikultural eksternal adalah multikulturalitas Kepulauan Masalembuyang didasarkan atas kedatangan investor-investor asing yang bertempat tinggal di Kepulauan Masalembu.

Olehnya, keberadaan multikultural tersebut akan mempengaruhi cara pandang dan interaksi sosial sehingga memerlukan pola dan konsep pemberdayaan masyarakatyang sesuai dengan realitas multicultural masyarakat yaitu melalui Pendidikan Multikultural. Pendidikan Multikultural di Kepulauan Masalembusangatlah penting dengan tujuan memahamkan adanya cara pandang masyarakat agar toleran, pluralis dan santun

\footnotetext{
${ }^{22}$ Mundzier Suparta, Islamic Multicultural Education: Sebuah Refleksi Atas pendidikan Agama Islam Di Indonesia, (Jakarta: Al Ghazali Center, 2008), 34-37.

${ }^{23}$ Blum, Antirasisme, Multikulturalisme, dan Komunitas Antar Ras, Tiga Nilai Yang bersifat Mendidik Bagi Sebuah Masyarakat Multikultural, dalam Larry May, dan Shari Colins-Chobanian, Etika Terapan:
} 
Miftahol Arifin, Pendidikan Multikultural di SMAN 1 Masalembu Sumenep (Studi Pada Mata Pelajaran Pendidikan Agama Islam Aspek Fiqh)

dalam memahami budaya lain seperti tradisi shalat Jenazah, shalat Khusuf, sistem pernikahan dan jual beli "urub” atau barter dan lain-lain.

Shalat Jenazah bagi suku Bugis, Mandar, Button dan Bajo adalah pamali atau dengan kata lain tidak dilaksanakan oleh suku mereka. Sedangkan suku Jawa dan Madura melaksanakan shalat Jenazah. Penuturan tentang mengapa shalat Jenazah tidak dilaksanakan oleh suku Bugis, Mandar, Button dan Bajo melainkan diserahkan kepada Modin dan para kyai, karena anggapan suku Bugis Mandar, Button dan Bajo bahwa pelaksanaan shalat Jenazah hanya boleh dilaksanakan bagi orang-orang yang suci sebagai penghantar orang yang menghadap Allah SWT. Olehnya shalat Jenazah dilaksanakan tidak oleh sembarang orang melainkan harus dilaksanakan oleh orang yang suci agar diterima disisi Allah SWT. Lain halnya tradisi masyarakat suku Jawa dan Madura shalat Jenazah tetap dilaksanakan oleh siapapun yang sudah baligh dan mampu melaksanakan shalat Jenazah.

Tradisi gerhana rembulan pada masyarakat suku Bugis, Mandar, Button dan Bajo, sangatlah menarik untuk dicermati. Mereka setiap terjadi gerhana rembulan pasti dalam kondisi terjaga (terbangun dari tidur) karena mereka harus melakukan ritual memandikan anak perempuannya yang masih gadis menuju tujuh sumur. Memandikan anak perempuan yang masih gadis atau anak perempuanyang belum menikah dengan tujuh sumur ketika terjadi gerhana rembulan merupakan "keberkahan" bagi si gadis atau anak perempuan yang belum menikahagar cepat mendapatkan jodoh. Donceng menuturkan, gerhana rembulan merupakan "berkah" bagi gadis-gadis atau anak perempuan yang belum menikah dari suku Bugis, Mandar, Button dan Bajo, karena mereka akan cepat mendapatkan jodoh manakala gerhana rembulan tiba, orang tua gadis atau anak perempuannya yang belum menikah, memandikannya di tujuh sumur.

Tradisi orang Jawa dan Madura jika ada gerhana rembulan, mereka menabuh apa saja yang ada seperti ember, panci dan lain sebagainya untuk membangunkan segala sesuatu yang ada disekitarnya seperti pohon, binatang dan lain sebagainya. Menurut M. Sakim, tradisi seperti itu adalah agar semua yang ada di alam ini terhindar dari bencana dan malapetaka, seperti tanaman singkong dan pisang agar buahnya tidak membusuk dan dapat dimanfaatkan secara baik.

Sebuah Pendekatan Multikultural, Alih Bahasa: Sinta Carolina dan Dadang Rusbiantoro, (Yogyakarta: Tiara Wacana, 2001), 19. 
Tradisi proses pernikahan bagi suku Bugis, Mandar, Button dan Bajo adalah menggunakan pola "aqad tawar-menawar" yaitu khitbah dan mahar yang mencapai harga puluhan juta rupiah dalam tawar-menawar. Tawar-menawar yang berupa uang pada waktu khitbah merupakan tradisi masyarakat suku Bugis, Mandar, Button dan Bajo, yang turun-temurun sebagai upaya pelapasan atau keridhoan orang tua terhadap anak perempuannya yang akan di lamar seorang laki-laki. Sebagaimana penuturan Rasi', bahwa proses lamaran melalui "tawar-menawar" harga merupakan adat-istiadat masyarakat suku Bugis, Mandar, Button dan Bajo, karena mempertimbangkan beberapa hal; pertama, pelepasan orang tua terhadap anak perempuannya dimana pihak laki-laki harus mengganti dana perawatan orang tua terhadap anak perempuannya. Kedua, martabat dan prestise orang tua di tengah-tengah masyarakat. Ada asumsi dasar bagi masyarakat Bugis, Mandar, Button dan Bajo, bahwa semakin mahal harga anaknya maka semakin tinggi tingkat prestise keluarga. Ketiga, ikatan kekeluargaan yang kuat yaitu pihak orang tua perempuan akan menjaga sekuat tenaga agar anak perempuannya tidak dimiliki oleh laki-laki lain, atau dengan kata lain anak perempuan adalah harga diri keluarga. Hal ini berlainan dengan tradisi perkawinan suku Jawa dan Madura yang tidak mematok harga bahkan cukup dengan seperangkat alat shalat.

Jual beli "urub" atau barter merupakan realitas perdagangan keseharian masyarakat Kepulauan Masalembuseperti urup ikan dengan beras, baju, pisang dan lain sebagainya. Jual beli "uruban" ini adalah sesuatu yang sudah mentradisi di seluruh masyarakat Kepulauan Masalembuseperti urub pisang dengan solar, urub ikan dengan dengan bahan pokok makanan, baju dan lain sebagainya. Menurut Mbah Parini, tradisi "urub" disebabkan adanya kondisi Kepulauan Masalembuyang jauh dari pusat kota dan tidak adanya pasar, sehingga uang bukan menjadi satu-satunya alat untuk menukar atau mendapatkan sesuatu atau barang. Olehnya, tradisi "urub" melekat sampai sekarang bahkan lebih mudah mendapatkan sesuatu atau barang melalui "urub" daripada dengan uang.

Problematika multikultural di atas, membutuhkan institusi pendidikan yang mampu mendesain pendidikan multikultural yang terencana secara sistematis dan akomodatif, sehingga mampu mengubah cara pandang, memperluas wawasan dan mempunyai sikap toleran, pluralis dan santun terhadap budaya lain.

\section{Model Strategi Pembelajaran Akomodatif SMAN 1 Masalembu Sumenep}


Miftahol Arifin, Pendidikan Multikultural di SMAN 1 Masalembu Sumenep (Studi Pada Mata Pelajaran Pendidikan Agama Islam Aspek Fiqh)

Strategi pembelajaran yang mampu merespon kemampuan dan karekteristik siswa diperlukan dalam rangka mengasah pola fikir siswa dalam memahami pelajaran dan informasi pengetahuan. Pendidik diharuskan mampu memahami kondisi dan realitas lingkungan siswa sehingga guru/pendidik mampu merencanakan strategi pembelajaran yang baik sehingga tujuan pendidikan dapat tercapai, seperti halnya pembelajaran mata pelajaran PAI aspek Fiqh yang terdapat di SMAN 1 Masalembu Sumenep yang mempunyai siswa dengan latar belakang budaya yang beragam, maka proses pembelajarannya pun menggunakan model strategi pembelajaran yang mampu memahami kultur siswa yang beragama atas dasar penelitian dan rumusan yang dilakukan oleh pendidik/guru melalui model strategi pembelajaran yang disebut Strategi Pembelajaran Akomodatif.

Strategi pembelajaran akomodatif adalah strategi pembelajaran yang didesain dan direncanakan untuk mengembangkan pengetahuan dan sikap siswayang toleran, pluralis dan santun terhadap keragaman budaya disekitarnya. Prinsip strategi Pembelajaran Akomodatif ini meliputi; (1) pengembangan pengetahuan dan sikap, (2) toleransi, pluralis dan santun, (3) penghargaan terhadap keragaman budaya. Tujuan Pembelajaran Akomodatif adalah memotivasi siswa untuk memiliki pengetahuan tentang keragaman budaya dan memiliki sikap yang toleran, pluralis dan santun terhadap budaya lain disekitarnya. Model pembelajaran yang digunakan pada strategi Pembelajaran Akomodatif adalah; Pertama, Orientasi Masalah. Orientasi merupakan awal pembelajaran yang dilakukan guru kepada siswa sebagai motivasi untuk responsif terhadap problem yang akan ditawarkan. Kemauan dan kemampuan siswa dirangsang untuk dapat dituangkan dan diaplikasikan pada problem yang ditawarkan sesuai dengan kemampuan yang dimiliki tanpa ada intervensi dari guru/pendidik.

Kedua, Membentuk Kelompok Diskusi. Langkah berikutnya adalah membentuk kelompok-kelompok diskusi yang memungkinkan siswa dapat berekspresi dan berkompetisi secara wajar dalam memberikan argumen yang telah mereka amati dan rumuskan. Kelompok diskusi siswa tidak dibagi atas dasar kesukuan mereka tapi campuran dari kesukuan mereka. Atau dengan kata lain tidak membedakan antara satu dengan yang lain. Ketiga, Pengamatan Sederhana. Pengamatan sederhana adalah upaya mengasah kepekaan dan realitas sosial didalam dan diluar diri siswa agar mampu mereka-reka realitas dan kemudian mampu mendefinisikan dan menganalisis sendiri ter- 
hadap apa yang mereka amati. Keempat, Penulisan Paper. Penulisan paper adalah tulisan yang disusun hasil dari pengamatan mereka sendiri baik berupa definisi, kegunaan dan langkah-langkah yang mereka anggap baik untuk memecahkan problem yang telah ditawarkan. Yang membuat definisi, kegunaan dan lain sebagainyaadalah mereka sendiri tanpa intervensi guru/pendidik.

Kelima, Diskusi. Diskusi merupakan upaya ekspresi aktualisasi dan sikap siswa dalam mempresentasikan papernya hasil dari pengamatan yang mereka lakukan. Semua pelaksanaan diskusi dilakukan oleh mereka sendiri dan mereka yang menyimpulkan hasil diskusi. Keenam, Kesimpulan. Kesimpulan dari semua pembahasan yang mereka lakukan merupakan hasil dari pengamatan dan pembacaan mereka terhadap realitas yang mereka hadapi. Pendidik/guru hanya memberikan tambahan-tambahan yang memberikan cakrawala yang lebih dari pemahaman yang mereka dapat dari pengamatan yang mereka lakukan.

\section{Penutup}

Berdasarkan uraian di atas dapat disimpulkan bahwa (1) Model Pendidikan Multikultural yang dilakukan oleh SMAN 1 Masalembu Sumenep atas dasar pluralitas masyarakat adalah menggunakan model Strategi Pembelajaran Akomodatif yaitu strategi pembelajaran yang didesain dan direncanakan untuk mengembangkan pengetahuan dan sikap siswa yang toleran, pluralis dan santun terhadap keragaman budaya disekitarnya. Prinsip Strategi Pembelajaran Akomodatif adalah (a) pengembangan pengetahuan dan sikap. (b) toleransi, pluralis dan santun. (c) penghargaan terhadap keragaman budaya.

Pendidikan multikultural yang dikembangkan di SMAN 1 Masalembu Sumenep memiliki Rencana Program Pembelajaran yang jelas sehingga mampu memberikan pemahaman dan membentuk sikap mental siswa dalam memahami mata pelajaran Fiqh dan realitas budaya disekitarnya. Rencana Program Pembelajaran (RPP) tersebut meliputi; (1) orientasi masalah yang dipaparkan oleh guru sebelum pembelajaran pokok dimulai sehingga siswa mempunyai bekal untuk memahami dan menganalisis masalah yang akan mereka pelajari dan diskusikan. (2) Membentuk kelompok diskusi, adalah upaya membagi siswa dalam beberapa kelompok untuk mengerjakan tugas-tugas agar siswa mampu berinteraksi dan dinamis. (3) Pengamatan sederhana, adalah upaya mengasah kepekaan siswa terhadap realitas sosial dan budaya dilingkungan sekitarnya. 
Miftahol Arifin, Pendidikan Multikultural di SMAN 1 Masalembu Sumenep (Studi Pada Mata Pelajaran Pendidikan Agama Islam Aspek Fiqh)

(4) Penulisan paper, adalah tulisan yang disusun oleh siswa hasil dari pengamatan sederhana yang telah mereka lakukan. (5) Diskusi, adalah presentasi siswa hasil dari penulisan paper yang mereka susun. (6) Kesimpulan, adalah rangkuman terhadap pembahasan dan penemuan-penemuan yang telah mereka amati, tulis dan diskusikan tanpa ada intervensi dari guru sedikitpun

Apresiasi siswa terhadap keragaman budaya disekitarnya sangat lah akomodatif. Hal ini dapat dilihat dari relasi siswa dengan siswa yang lain dan relasi siswa dengan masyarakatnya. Apresiasi siswa Bugis, Mandar, Button dan Bajo dengan siswa Jawa dan Madura, demikian juga sebaliknya mereka memberikan rasa hormat dan toleransi tanpa ada ejekan satu sama lainnya. Mereka memahami perbedaan budaya yang mereka miliki sehingga mereka memiliki rasa empati, kebersamaan dan toleransi satu sama lain, sikap ini mereka tunjukkan baik didalam kelas maupun di luar kelas.

Sedangkan apresiasi siswa terhadap masyarakatnya adalah baik siswa dari suku Bugis, Mandar, Button dan Bajo maupun siswa dari suku Jawa dan Madur memahami keberadaan budaya masyarakatnya yang beragam sehingga siswa mampu memahami dan memilah antara tradisi budaya yang terjadi di masyarakat, seperti pamali dalam shalat Jenazah, budaya gerhana rembulan, sistem pernikahan yang menggunakan "tawar-menawar, dan jual beli dengan sistem urub/barter dengan mata pelajaran Fiqh yang mereka pelajari di Sekolah. 


\section{DAFTAR PUSTAKA}

Zakiyuddin, Baidhawi. 2005. Pendidikan Agama Berwawasan Multikultur. Jakarta:: Erlangga.

Gwendolyn, C, Baker. 1994. Planning and Organizing for Multicultural Instruction, Amerika: Addison-Wesley Publishing Company.

Banks. 1984. Teaching Strategies For Ethnic Studies. Newton: Allyn and Bacon.

Bennett, Christin I. 1995. Comprehensive Multicultural Education: Theory and Practice. Amerika: A Simon \& Schuster Company.

Blum. 2001. Antirasisme, Multikulturalisme, dan Komunitas Antar Ras, Tiga Nilai Yang bersifat Mendidik Bagi Sebuah Masyarakat Multikultural, dalam Larry May, dan Shari Colins-Chobanian, Etika Terapan: Sebuah Pendekatan Multikultural, Alih Bahasa : Sinta Carolina dan Dadang Rusbiantoro, Yogyakarta: Tiara Wacana.

Dawam, Ainurrofiq, "EMOH” Sekolah: Menolak "Komersialisasi Pendidikan” dan “Kanibalisme Intelektual” menuju Pendidikan Multikultural, (Yogyakarta: Inspeal Ahimsakarya Press.2003)

Driyarkara. 1980. Tentang Pendidikan. Jakarta: Kanisius.

Judistira, K, Garna. 2003. Ilmu-ilmu Sosial: Dasar-Konsep-Posisi. Bandung: Primaco Akademika.

Zahara, Idris. 1987. Dasar-Dasar Kependidikan. Padang: Angkasa Raya.

Kymlicka. 2002. Kewargaan Multikultural, alih bahasa Edlina Hafmini Eddin, Jakarta: LP3ES.

Maksum, Ali dan Luluk Yunan Ruhendi Maksum. 2004. Paradigma pendidikan Universal di Era Modern dan Post-Modernisme. Jogyakarta: IRCiSod.

Manning dan Barruth. 2000. Multicultural Education of Children and Adolescent. Amerika: A Pearson Education Company.

Maslikhah. 2007. Quo Vadis Pendidikan Multikultural: Reconstruksi Sistem Pendidikan berbasis Kebangsaan. Surabaya: JP Books.

Marimba, Ahmad D. 1998. Pengantar Filsafat Pendidikan Islam. Bandung: PT alMa'arif. 
Miftahol Arifin, Pendidikan Multikultural di SMAN 1 Masalembu Sumenep (Studi Pada Mata Pelajaran Pendidikan Agama Islam Aspek Fiqh)

Salim, Agus. 2004. "Pendidikan Multikultural" dalam Indonesia Belajarlah: Membangun Pendidikan Indonesia. Semarang: Gerbang Madani Indonesia.

Santrock, John W. 2007. Psikologi Pendidikan, alih bahasa Tri Wibowo B.S. Jakarta: Kencana. 184.

Sleeter. 1992. "Restrusturing Schools for Multicultural Education”,dalam Journal of Teacher Education ed. 43.

Stavenhagen, 1986. Problems and Prospects of Multiethnic States. Tokyo: United Nations University Press.

Suparta, Mundzier. 2008. Islamic Multicultural Education: Sebuah Refleksi Atas pendidikan Agama Islam Di Indonesia. Jakarta: Al Ghazali Center.

Tilaar, H.A.R. 2004. Multikulturalisme: Tantangan-tantangan Global Masa Depan dalam Transformasi Pendidikan Nasional. Jakarta: Grasindo.

. 2002. Perubahan Sosial dan Pendidikan: Pengantar Pedagogik Transformatif untuk Indonesia. Jakarta: Grasindo.

Yaqin, M. Ainul. 2005. Pendidikan Multikultural: Cross-Cultural Understanding untuk Demokrasi dan Keadilan. Yogyakarta: Pilar Media. 